\title{
ROTAČNÁ KAPACITA PRÍPOJOV NA MOSTNÝCH KOŠTRUKCIÁCH
}

\section{THE INITIAL ROTATIONAL STIFFNESS OF CONNECTIONS ON THE BRIDGE STRUCTURES}

\author{
Róbert Štecák ${ }^{*}, 1$ \\ "robert.stecak@stuba.sk \\ ${ }^{1}$ Slovenská technická univerzita v Bratislave, Stavebná fakulta, Katedra kovových a drevených konštrukcií, Radlinského 11, 81005 \\ Bratislava, Slovenská republika
}

\begin{abstract}
Abstrakt
Výpočet rotačnej kapacity prípojov na ocel'ových mostoch je nesmierne dôležitou súčast'ou výpočtov. Zväčša železničné mosty majú často viac ako 60 rokov. Tieto mosty sú stále zat'ažované vlakovou dopravou a ich diagnostika je nevyhnutná, pre ich bezpečné fungovanie. Práve prípoje sú kritickým miestom. Ich správny výpočet je dôležitý pre správe určenie ich životnosti či zat’ažitel'nosti. Práve rotačná kapacita umožňuje namodelovat' prípoje tak, aby čo najviac zachytili realitu. Nanešt’astie, postup v Eurokóde nie je úplne jasný. Výpočet rotačnej kapacity je v norme uvádzaný len pre budovy, nie však pre horizontálne konštrukcie ako sú mosty.
\end{abstract}

\section{Kl'účové slová}

Most, rotačná kapacita, prípoje, ocel’

\begin{abstract}
The calculation of the initial rotational stiffness of bridge connection is immensely important element of calculations. Generally, railway bridges are more than 60 years old. These bridges are still burdened by train traffic. The diagnostic of bridges is necessary to safety functioning. The connections are critical point. Their correct calculation is essential for the administration to determine their service life and load capacity. It is the initial rotational stiffness that allows the connections to be modelled so that they capture reality as much as possible. Unfortunately, the procedure in the Eurocode is not clear. The calculation is defined only for building, not horizontal structures such as bridges.
\end{abstract}

Key words

Bridge, initial rotational stiffness, connection, steel

\section{1 ÚVOD}

Na Slovensku je mnoho železničných mostov. Väčšina starších mostov má prípoje spájané nitmi. Mnoho z nich má viac ako 60 rokov. Účinok únavy môže zmenit’ niektoré vlastnosti nosných prvkov konštrukcie. To môže zapríčinit', že konštrukcia nemusí vyhovovat' pre súčasnú dopravu. Najproblematickejšie miesto sú prípoje. Väčšinou sú prípoje počítané ako kíbové prípoje. To však nie je úplná pravda. Prípoj môže byt' tuhý, polotuhý alebo nominálne kĺbový. Toto je klasifikácia v elastickej oblasti podl’a Eurokódu 3-1-8 [1]. Rotačná kapacita určuje toto usporiadanie prípojov. Táto metóda tak umožňuje určit' tuhost' prípojov a objektu celkovo.

Rotačná kapacita je v Eurokóde definovaná len pre budovy so stípom a vodorovnými nosníkmi. Nie je tam jasne vymedzená definícia mosty. Postup podl’a Eurokódu je v takomto prípade náročný. Najvhodnejšie je preto použit' program pre výpočet rotačnej kapacity. V tomto prípade bol použitý program IDEA StatiCa. Je to program určený pre modelovanie a posudzovanie prípojov. Okrem tradičného analýzy dokážu určit’ aj rotačnú kapacitu.

Rotačná kapacita bola vypočítaná v programe, následne program zatriedil prípoj do príslušnej triedy. Pre overenie bola prevzatá programu hodnota rotačnej kapacity prípoja Sj,ini. Potom bola zatriedená podl'a postupu v Eurokóde[1] a porovnaná so zatriedením v programe. 


\section{ROTAČNÁ KAPACITA PRÍPOJA}

Tuhost' prípoja je jeho schopnost' odolávat' deformácii vzhl'adom na aplikovanú silu. Tuhost' je vzt'ah medzi aplikovanou silou a posunutím, ktoré sila vyvoláva.

\begin{tabular}{|l|l|l|l|}
\hline \multicolumn{1}{|c|}{$\begin{array}{c}\text { Metóda globálnej } \\
\text { analýzy }\end{array}$} & \multicolumn{2}{c|}{ Klasifikácia uzla } \\
\hline Pružnostná & Nominálne kĺbový & Tuhý & Polotuhý \\
\hline Tuhostno - plastická & Nominálne kíbový & S plnou únosnostou & S čiastočnou únosnost'ou \\
\hline $\begin{array}{l}\text { Pružnostno- } \\
\text { plastická }\end{array}$ & Nominálne kíbový & Tuhý s plnou únosnostou & $\begin{array}{l}\text { Polotuhý s čiastočnou únosnost'ou } \\
\text { Polotuhý s plnou únosnostou } \\
\text { Tuhý s čiastočnou únosnostou }\end{array}$ \\
\hline Typ mode lu uzla & KÍbový & Spojitý & Čiastočne spojitý \\
\hline
\end{tabular}

Obr. 1 Typy modelov uzlov [1].

Existuje viacero metód globálnej analýzy pre výpočet prípoja. Najčastejšia je pružnostná analýza. V tomto prípade bola použitá pružnostná analýza. Najkomplikovanejšie je vypočítat' súčinitel' Sj,ini. Použitie iba Eurokódu je náročné. Analýza zaberie mnoho času, navyše presnost' výsledku môže byt' relatívne nízka. V tomto prípade bol použitý výpočet v programe Idea StatiCa, ktorý dokázal vyrátat’ súčinitel' Sj,ini. Dokonca program dokázal určit' aj hranice pre klasifikáciu spojenia.

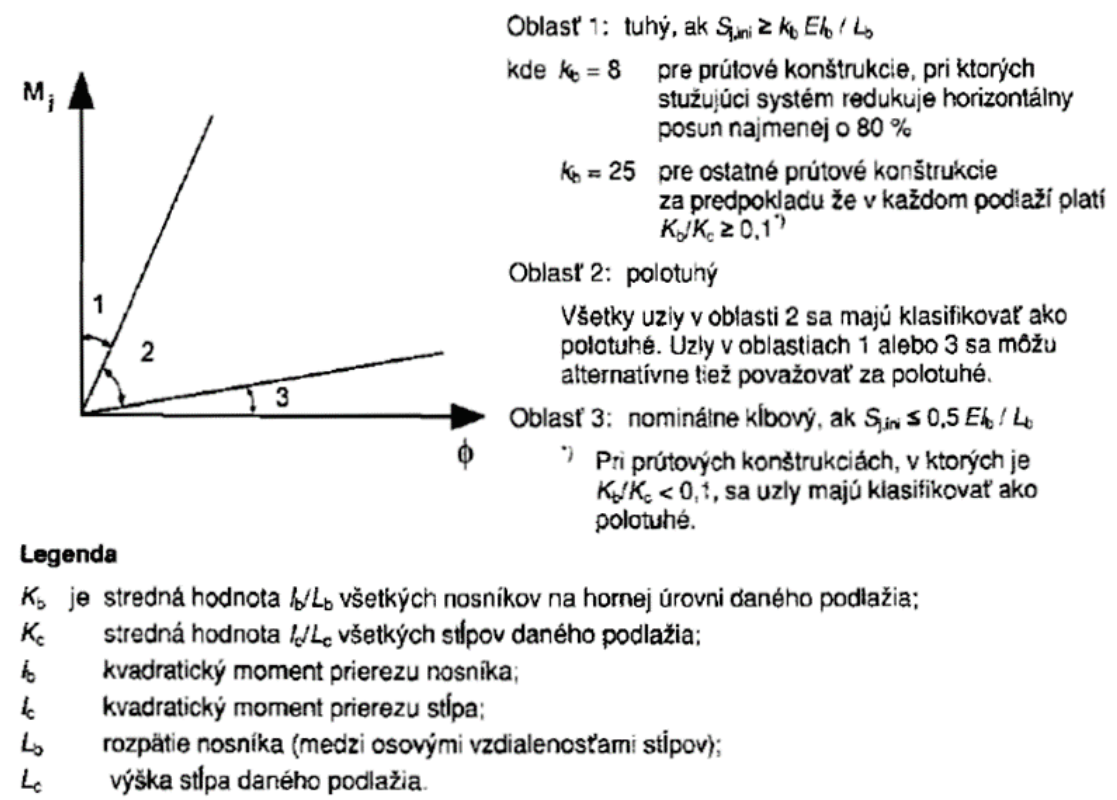

Obr. 2 Hranice zatriedenia [1].

Hranice sú zadefinované pre budovy. Práve to bol dôvod, pre overenie správnej klasifikácie programu. Preskúmanie bolo vykonané s existujúcim súčinitel’om $\mathrm{Sj}$,ini, vybraného z programu a následného manuálneho výpočtu. 


\section{VÝPOČET}

Pre výpočet bol použitý prípoj z existujúceho železničného mosta pri obci Nižná Myšl’a. Jedná sa o priehradový most s otvorenou mostovkou. Všetky prípoje sú nitované. V programe nebolo možné zadefinovat' nity, takže boli namodelované ako skrutky s materiálovými vlastnost’ami rovnakými ako je ocel', z ktorej je konštrukcia. Jednotlivé nosníky boli pripojené pomocou L profilov. Na druhej strane bol namodelovaný plech o hrúbke 30mm, ktorý nahrádzal nosník. Ked’že spoj bol symetrický, v prípade namodelovania nosníkov z oboch strán dochádzalo ku kolíziám vo výpočte.

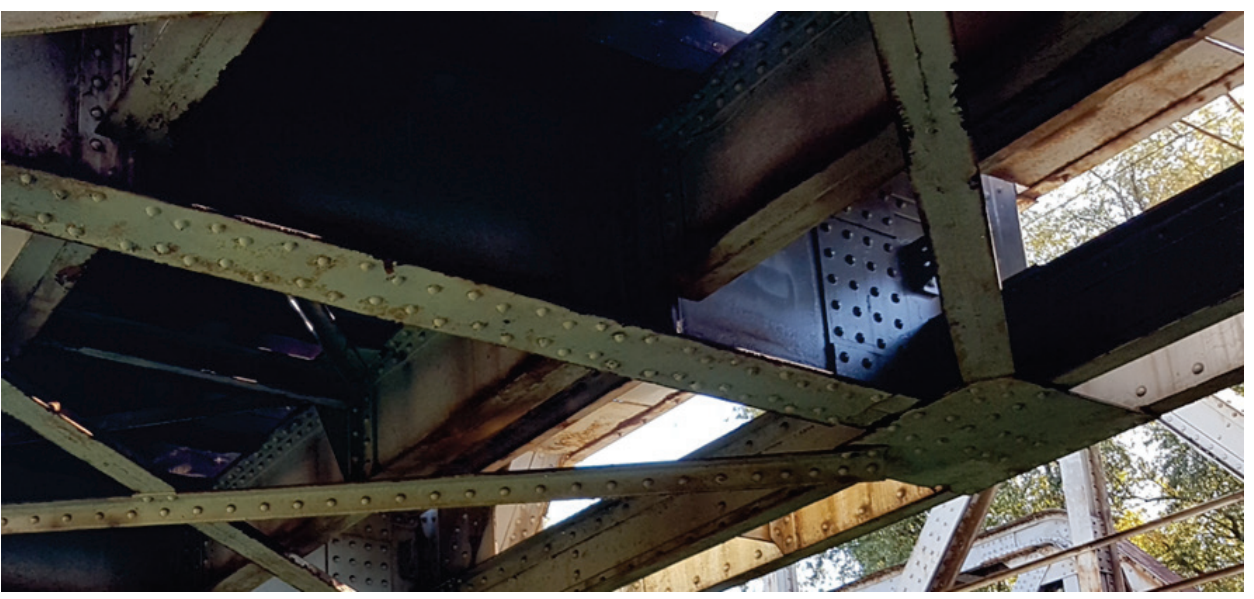

Obr. 3 Modelovaný prípoj v skutočnosti.

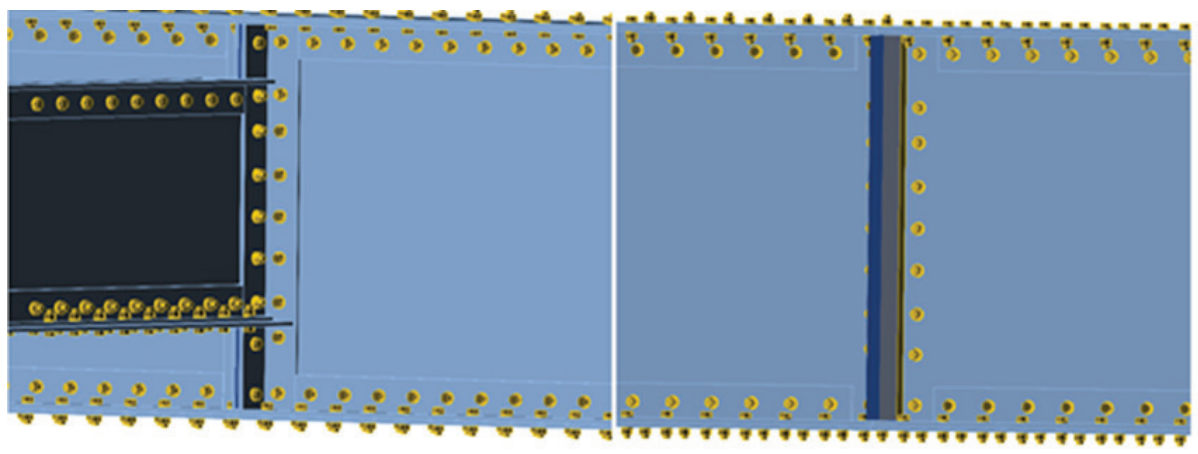

a)

b)

Obr. 4 Model prípoja a) pohl'ad spredu b) pohl'ad zozadu.

Tab. 1 Hodnoty rotačnej kapacity získané z programu.

\begin{tabular}{cccccccc}
\hline Komp. & $\begin{array}{c}\mathbf{M j}, \mathbf{R d} \\
{[\mathbf{k N} / \mathbf{m}]}\end{array}$ & $\begin{array}{c}\mathbf{S j}, \mathbf{i n i} \\
{[\mathbf{M M N m} / \mathbf{r a d}]}\end{array}$ & $\begin{array}{c}\mathbf{\Phi c} \\
{[\mathbf{m r a d}]}\end{array}$ & $\begin{array}{c}\mathbf{L} \\
{[\mathbf{m}]}\end{array}$ & $\begin{array}{c}\mathbf{s j}, \mathbf{R} \\
{[\mathbf{M N m} / \mathbf{r a d}]}\end{array}$ & $\begin{array}{c}\mathbf{S j}, \mathbf{P} \\
{[\mathbf{M N m} / \mathbf{r a d}]}\end{array}$ \\
\hline $\mathbf{M y}$ & 46,2 & 17,4 & 3,3 & 3,6 & 1112,3 & 22 & $k$ klbový \\
$\mathbf{M z}$ & 7 & 0,1 & 517,6 & 3,6 & 51,1 & 1 & $k$ lbový \\
\hline
\end{tabular}

Výpočet bol uskutočnený pre prvky o skutočnej dížky. Ked’že tento parameter vstupuje do výpočtov, je nesmierne dôležité dodržat' geometriu. Softvér ma predvolenú dížku nosníkov, ked'že pri výpočte spojov nehrá dížka nosníka rolu. Dížka sa ale dá zmenit'. Zat'aženie bolo nastavené vo všetkých smeroch ako sily o vel'kosti 
$1 \mathrm{kN}$ a ohybové momenty $1 \mathrm{kNm}$. Vel'kost' zat'aženia nemá vplyv na výpočet kapacity a jednotkové zat'aženie zrýchlilo dobu trvania výpočtu. Výsledky sú v Tab. 1. Hodnoty Sj,ini boli potom vybrané do výpočtu.

Po výpočte v programe začal manuálny výpočet. Výpočet prebehol pomocou Eurokódu 1993-1-8, ako bolo uvedené v Obr. 2. Následne boli výsledky porovnané s programom. Zatriedenie vyšlo rovnaké. Konkrétne hodnoty boli mierne odlišné, ale nemalo to vplyv na zatriedenie. Nanešt’astie, manuál pre program IDEA Statica chýba, takže je náročné overit', čo mohlo byt' dôsledkom rozličných hodnôt a aké postupy sú v programe určené.

\section{VPLYV ROTAČNEJ KAPACITY NA KONŠTRUKCIU}

Tab. 2 Výsledky získané pomocou Eurokódu 1993-1-8.

\begin{tabular}{ccccc}
\hline & $\begin{array}{c}\text { Rotačná kapacita } \\
\text { Sj,ini } \\
{[\mathbf{M N m}]}\end{array}$ & $\begin{array}{c}\text { Tuhý prípoj } \\
\text { KbEIb/Lb } \\
{[\mathbf{M N m}]}\end{array}$ & $\begin{array}{c}\text { Nominálne kíbový pripoj } \\
\mathbf{0 , 5} \text { Ib/Lb } \\
{[\mathbf{M N m}]}\end{array}$ & Výsledok \\
\hline Ohybový moment $\mathbf{M y}$ & 46,2 & 17,4 & 3,3 & 3,6 \\
Ohybový moment $\mathbf{M z}$ & 7 & 0,1 & 517,6 & 3,6 \\
\hline
\end{tabular}

Výpočet rotačnej kapacity umožňuje zatriedit’ prípoj do danej triedy. To ale nie je všetko. Hodnota Sj, ini môže vstupovat' do výpočtu. V skutočnosti spoje nie sú ani dokonalý kíb, ani dokonalo tuhé. Práve zavedenie hodnoty Sj,ini umožňuje zachytit’ reálny stav konštrukcie a získat' tak čo najpresnejšie výsledky.

Program RFEM od spoločnosti Dlubal umožňuje zadefinovat' rotačnú kapacitu. Pre výpočet bol použitý rovnaký model ako v predošlom výpočte. V tomto prípade bol však model zadefinovaný ako prútový model, nie model z konečných prvkov. Výpočet tol'kého množstva konečných prvkov by bol extrémne zdlihavý. Sledované boli celkové vnútorné sily, nie lokálne napätia na nosníkoch, takže aj prútový model bol postačujúci.

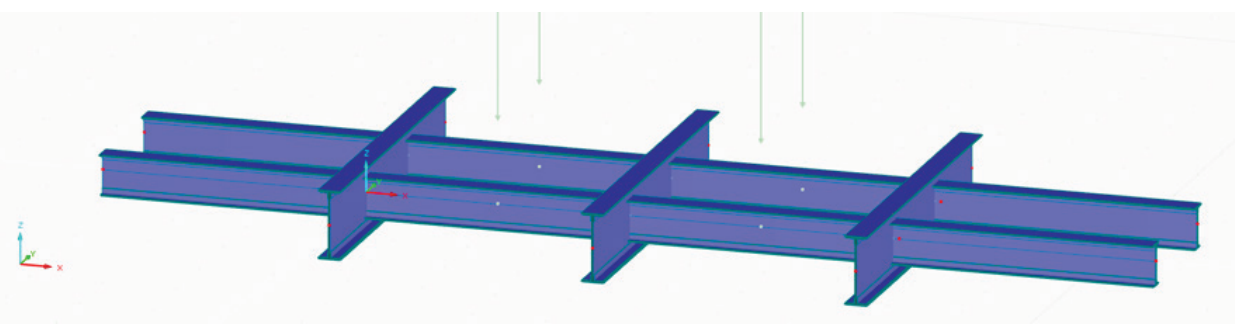

Obr. 5 Schéma zat'aženia na modeli.

Namodelované boli 3 modely. S nominálnym kíbom, tuhý a prípoj s konkrétnou rotačnou kapacitou. Zat’aženie bolo nastavené ako dvojica síl, každá o vel'kosti 100 kN v strede rozpätia nosníkov. Model je znázornený na Obr. 5 . V programe ako je RFEM sa prípoj nedefinuje detailne ako v programe IDEA. Zadefinuje sa len koncové uloženie nosníka. Preto je potrebné dat' pozor, ako je definovaný prípoj nosníka na d’alší nosník. Okrajové podmienky uloženia priečnikov boli namodelované ako tuhé pripojenie, čiže votknutie.

Rozdiel medzi ohybovým momentom pri jednotlivých momentoch bol výrazný. Medzi tuhým prípojom a prípojom s konkrétnou hodnotou $\mathrm{Sj}$,ini je rozdiel $40 \%$. To je ohromný rozdiel. Rozdiel medzi nominálnym kíbom a prípojom s konkrétnou hodnotou $\mathrm{Sj}$,ini je $10 \%$. To je relatívne malý rozdiel. Na obrázku 5 sú znázornené priebehy vnútorných síl

V prípade, že sa modeluje konštrukcia s tuhými prípojmi, prikláňame sa na stranu menej bezpečnú. 


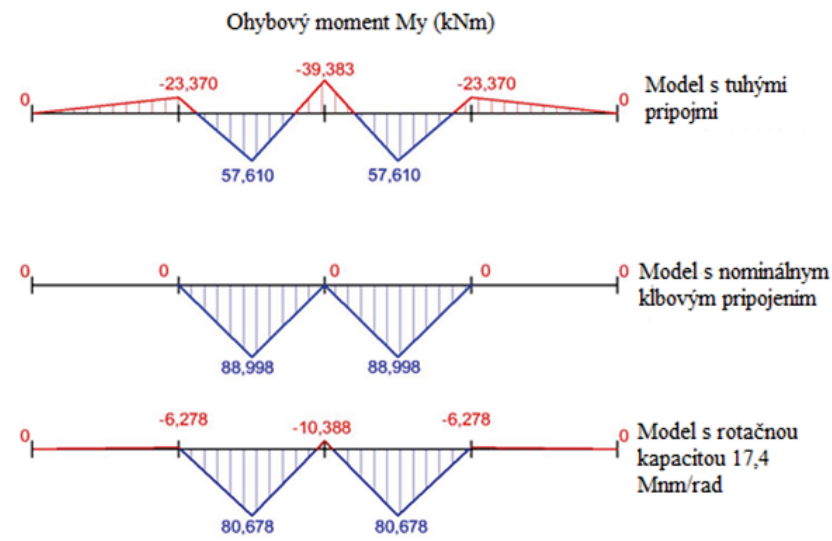

Obr. 6 Hodnoty ohybových momentov.

\section{ZÁVER}

Rotačná kapacita má mimoriadne vel'ký vplyv na návrh prípojov. Ako bolo ukázané, vplyv zadania rotačnej kapacity Sj,ini má kl’účovú rolu na celkový výsledok vnútorných síl. Pri ocel’ových konštrukciách majú únava, korózia a iné faktory obrovský vplyv na zbytkovú únosnost'. Je preto nevyhnutné vytvorit' čo najpresnejší výpočtový model. Výpočet len pomocou Eurokódu 1993-1-8 je zdíhavý. Celkový postup je neprehl'adný a nie je ho možné l'ahko aplikovat' aj na mostné konštrukcie. Vzhl'adom na možnosti v súčasnosti, je najrýchlejšou možnost'ou použit' výpočtový program, ktorý dokáže vypočítat' rotačnú kapacitu prípoja. Ako bolo dokázané, výpočtový program dokáže určit' rotačnú kapacitu takmer rovnako ako norma. Navyše, namiesto zdíhavého ručného výpočtu dokážu programy v súčasnosti zrátat' výsledky do niekol'kých minút.

\section{Použité zdroje}

[1] Eurokód 3 Navrhovanie ocel’ových konštrukcií: Čast’ 1-8: Navrhovanie uzlov. 2007. Bratislava: Slovenský ústav technickej normalizácie.

[2] B.F.M., PAZMIÑO. 2018. The Prediction of the Joint Stiffness in Riveted Steel Bridges. Praha. Diplomová práca. České vysoké učení technické v Praze. Školitel’ Doc. Ing. Pavel Ryjáček, Ph.D.

[3] J.C., Tarafdar. 2017. Initial Rotational stiffness. Research Gate [online]. Berlín: ResearchGate [cit. 202111-10]. Dostupné na internete: Tarafdar, J.. (2017). Re: Formula for rotational Stiffness. Retrieved from: https://www.researchgate.net/post/Formula-for-rotationalStiffness/5945def496b7e4e5445d13b8/citation/download. 